\title{
HUBUNGAN KARAKTERISTIK SEDIMEN DASAR TERHADAP KANDUNGAN MERKURI AKIBAT PERTAMBANGAN EMAS TANPA IJIN (PETI) PONGKOR - KAB. BOGOR
}

\author{
Hasmalina Nst, Gunawan Pratama Yoga, Latifah K. Darusman
}

\author{
Jurusan Kimia UMRI \\ Peneliti LIPI \\ Jurusan Kimia IPB
}

\begin{abstract}
ABSTRAK
Aktivitas ekstraksi bijih emas dengan gelundungan yang menggunakan merkuri oleh Pertambangan Emas Tanpa Ijin (PETI) Pongkor di Sungai Cikaniki, Kab. Bogor telah menimbulkan dampak yang negatif terhadap ekosistem air tawar, akibat pembuangan limbah tailling merkuri secara langsung tanpa pengolahan terlebih dahulu ke lingkungan perairan sehingga mengakibatkan pencemaran air dan sedimen. Kandungan Merkuri total yang terlarut dalam sampel air sungai dan sedimen dianalisa dengan Atomic Absorption Spectroscopy (AAS), karakteristik sedimen dasar dilakukan dengan ayakan bertingkat, sedangkan hubungan kadar merkuri dengan karakteristik fraksi penyusun sedimen ditentukan dengan analisis korelasi. Hasil pengukuran kandungan merkuri dalam air sungai keempat lokasi sampling ratarata berkisar ttd-0,265 ppm; dalam sedimen berkisar $<0,0002-196 \mathrm{ppm}$ dan karakteristik sedimen sungai Cikaniki rata-rata keempat lokasi terdiri dari pasir $73,9 \%$; lumpur $4,8 \%$; liat $21,3 \%$. Analisis korelasi menunjukkan adanya hubungan yang positif yang sangat erat antara fraksi halus (lumpur dan fraksi liat) sedimen dengan kadar merkuri dengan nilai koefesien korelasi (r) bulan Juni dan September berkisar antara $0.766-0.860$, sebaliknya korelasi yang negatif antara fraksi kasar (pasir) sedimen dan kadar merkuri dengan nilai koefesien korelasi (r) bulan Juni dan Spetember berkisar antara $-0.239--0.045$.
\end{abstract}

\section{PENDAHULUAN}

Pertambangan Emas Tanpa Ijin (PETI) adalah usaha pertambangan emas yang dilakukan oleh perseorangan, sekelompok orang, atau yayasan/perusahaan berbadan hukum yang dalam operasinya tidak memiliki izin dari instansi pemerintah pusat atau daerah sesuai dengan peraturan perundang-undangan. Aktivitas PETI umumnya menggunakan merkuri (air raksa/kuik) pada proses pengolahan biji emas.

Penggunaan merkuri untuk kegiatan PETI Pongkor tidak mengikuti peraturan yang ada (Peraturan Pertambangan dan Energi No.01.P/76.M.PE/1991 dan Keputusan Dir/Jen POM Departemen Kesehatan RI No. HK.00. 06.6.02818, tentang kesehatan kerja pada penggunaan, penyimpanan dan penanganan air raksa dalam usaha pertambangan bahan galian emas), karena masyarakat tidak tahu menahu tentang peraturan tetapi tahu bagaimana menambang emas dengan menggunakan merkuri. Jumlah merkuri yang digunakan dalam proses pengolahan dengan alat pemrosesan yang disebut gelundungan berkisar 0,5-1 $\mathrm{kg}$ untuk satu gelundungan yang berukuran 8-12 kg. Berdasarkan data dari Pemerintah Daerah Kabupaten Bogor tercatat lebih kurang 600 orang PETI pertahun. Menurut Halimah (2002) untuk lebih 900 lebih gelundungan digunakan merkuri 16,2 ton/bulan, dengan proses pengolahan yang sangat sederhana diperkirakan jumlah limbah merkuri yang terbuang langsung ke sungai Pongkor sebagai sisa proses adalah $30 \%$ x 16,2 ton $=4,86$ ton $/$ bulan.

Limbah merkuri adalah salah satu limbah B3 (Bahan Berbahaya dan Beracun). Merkuri dan turunannya tergolong sangat beracun dan bersifat akumulatif dan dapat menyebabkan keracunan akut dan kronis (Palar, 2004). Pencemaran merkuri memiliki pengaruh terhadap ekosistem disebabkan sifatnya yang stabil dalam sedimen dan sedimen mempunyai kapasitas yang besar untuk mengikat/mengakumulasi zat pencemar berupa logam berat dibandingkan air sungai. Pengikatan terjadi melalui proses pertukaran kation dari tanah dan sedimen dengan kation yang terikat oleh anion seperti klorida, sulfat dan karbonat yang umumnya terdapat dalam tanah 
atau sedimen. Kelarutan merkuri yang rendah dalam air, kemudahannya diserap dan terikat oleh senyawa organik dan anorganik, terkumpul dalam jaringan tubuh organisme air juga menjadi salah satu faktor semakin tingginya kandungan merkuri pada sedimen (Wang, S.X., et.al. 2003).

Berdasarkan pertimbangan diatas maka penulis tertarik untuk menentukan tingkat pencemaran merkuri pada air sungai dan sedimen dasar serta menganalisa bagaimana korelasi jenis fraksi yang terdapat pada sedimen dengan kadar merkuri yang dikandungnya.

\section{METODE PENELITIAN}

1. Sampel

Sampel yang digunakan pada penelitian ini adalah air dan sedimen dari sungai Cikaniki Pongkor, Penentuan lokasi sampling dilakukan dengan cara purposive sampling atau judgement, yang diambil dari empat lokasi sampling yaitu satu lokasi kontrol (Hulu Sungai) dan tiga lokasi adalah badan sungai yang banyak terdapat aktivitas PETI.

2. Metode Analisa Kadar merkuri yang digunakan adalah metode Spektroskopi Serapan Atom (SSA) dan karakteristik sedimen dasar dilakukan dengan ayakan bertingkat.

3. Alat dan Bahan

Alat-alat yang digunakan dalam penelitian ini adalah peralatan gelas, timbangan analitik, Spektroskopi Serapan Atom (SSA) merek HITACHI model 180-60/80, Z-6000/Z-8000 dan Z-6100/Z-8100, water sampler, ekman grab, skop polipropilen, seperangkat alat destruksi sedimen.

Bahan-bahan yang digunakan dalam penelitian ini adalah bahan-bahan kimia untuk sampling dan analisa air \& sedimen, larutan standar logam $\mathrm{Hg}, \mathrm{HNO}_{3}$ pekat, aquades.

4. Prosedur Penelitian

a. Pengambilan dan Penanganan Sampel

Sampel air dan sedimen diambil di sungai Cikaniki Pongkor yang tercemar oleh merkuri akibat aktivitas PETI. Sampel air dan sedimen diambil pada empat lokasi di badan sungai. Sampel air diambil dengan water sampler yang berkapasitas 1,20 liter, sedangkan sedimen diambil sampai ketebalan 6-10 cm dari permukaan zona deposit sedimen dengan menggunakan Ekman Grab dan Skop dari polipropilen dan dikumpulkan dalam plastik polietilen. Sampel air untuk analisa dengan AAS diawetkan dengan menggunakan asam nitrat pekat. Sampel sedimen disimpan pada suhu $4^{\circ} \mathrm{C}$.

b. Pengukuran Kadar Merkuri pada Air dan Sedimen

Kadar total merkuri didalam sederet larutan kerja yang dibuat dari larutan standar logam Merkuri, sampel air dan sedimen yang telah didestruksi diukur dengan menggunakan spektroskopi serapan atom (AAS).

c. Penentuan Karakteristik Sedimen Dasar Karakteristik atau distribusi fraksi penyusun sedimen ditentukan dengan menggunakan ayakan bertingkat. Masing-masing hasil pengayakkan ditimbang dengan timbangan analitik dan dihitung persentasenya.

d. Analisis Data

Data kadar merkuri dalam sampel air, sedimen, dan karakteristik sedimen dasar disajikan dalam bentuk grafik batang. Sedangkan hubungan antara kadar merkuri dengan fraksi sedimen disajikan dalam bentuk grafik garis dengan dua sumbu $\mathrm{Y}$ dan dianalisa korelasinya dengan mencari nilai kooefesien korelasi (r).

\section{HASIL DAN PEMBAHASAN}

Aktifitas Penambangan Emas Tanpa Ijin (PETI) di sungai Cikaniki Pongkor, Kabupaten Bogor telah dilakukan sejak tahun 1991, hingga saat ini aktifitas PETI berlangsung terus tanpa memperdulikan dampak negatif terhadap lingkungan sekitarnya terutama terjadinya pencemaran merkuri terhadap air, sedimen maupun biota air pada badan sungai. Sedimen memiliki kemampuan mengakumulasi kontaminan/zat pencemar dan bertindak sebagai sumber pencemar bagi ekosistem. Senyawa patogen, nutrien, logam-logam dan senyawa organik kimia cenderung terabsorbsi oleh bahanbahan organik dan anorganik yang akhirnya 
menetap dan mengendap pada daerah sedimentasi (Chapman, et.al. 1998).

Sampel yang digunakan dalam penelitian ini adalah air dan sedimen yang diambil dari empat lokasi sampling yaitu S1 = Cikaniki Hulu, S2 = Cisarua, S3 = Curug Bitung dan S4 = Lukut di sepanjang sungai Cikaniki Pongkor, Kab. Bogor.

Hasil pengukuran kadar merkuri pada sampel air pada setiap lokasi pengamatan berkisar antara ttd-0.046 ppm untuk bulan juni dan <0.0002-0.265 ppm untuk bulan September (Gambar 1). Rendahnya kadar merkuri pada bulan september dibandingkan bulan juni, diduga karena perbedaan waktu dan musim, bulan September cenderung berada pada musim hujan sehingga terjadi proses pengenceran. Kandungan logam berat dalam perairan yang melebihi batas untuk menjamin kehidupan biota air yang layak, akan berpengaruh buruk terhadap proses-proses biologi. Apabila ditinjau dari kadar merkuri saja dalam air, maka air sungai Cikaniki tidak layak digunakan untuk keperluan rumah tangga, karena kadar maksimum yang diperbolehkan bagi peruntukkannya menurut PP No. 82/th 2001 sebesar $0.001 \mathrm{mg} / \mathrm{l}$.

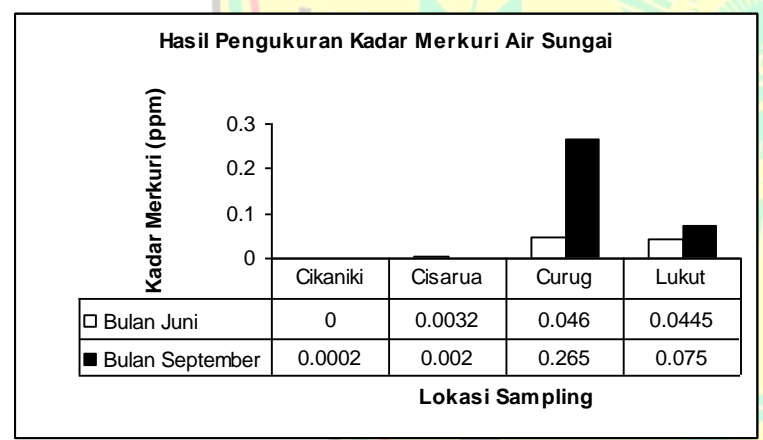

Gambar 1. Hasil Pengukuran kadar Merkuri Air Sungai

Hasil pengukuran kadar merkuri pada sampel sedimen yang berasal dari keempat lokasi berkisar antara <0.0002-163 ppm untuk bulan Juni dan 4.39-196 ppm untuk bulan September (Gambar 2). Dari grafik terlihat bahwa kadar terendah pengamatan bulan Juni dan September pada stasiun 1 (Cikaniki Hulu) dan tertinggi pada stasiun 4 (Lukut), hal ini karena sifat dari merkuri yang memiliki berat molekul dan berat jenis yang lebih besar dari air sehingga akibat adanya arus akan terbawa bersama partikel sedimen yang halus dan mengendap dibagian hilir sehingga terjadi akumulasi yang lebih besar dibandingkan stasiun sebelumnya.

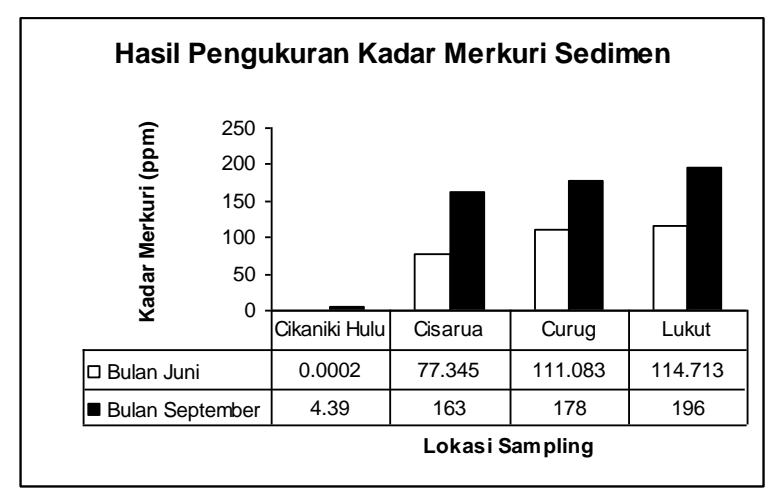

Gambar 2. Hasil Pengukuran Kadar merkuri pada Sedimen

Kadar merkuri yang terdapat di dalam sampel sedimen terlihat jauh lebih besar dari sampel air sungai. Hal ini karena merkuri yang sukar larut dalam air namun cenderung mudah terikat pada padatan tersuspensi dan mengendap ke dasar perairan dna bersatu dengan sedimen.

Dalam air sungai terdapat bagian koloid yang berasal dari bebatuan terkikis dan bagian tanah halus yang tersuspensi. Partikel-partikel ini mempunyai kemampuan besar untuk mengadsorpsi ion-ion logam berat. Logam berat yang terdapat dalam air sungai bersama-sama dengan partikel padat akan mengendap membentuk sedimen. Logam berat yang masuk ke perairan akan mengalami pengendapan, pengenceran dan disperse, kemudian dapat diabsorpsi dan diadsorpsi oleh organsme yang hidup di dasar perairan tersebut (Connell \& Miller, 1995).

Hasil Penentuan karakteristik fraksi sedimen menunjukkan bahwa fraksi pasir merupakan jenis substrat sedimen yang dominan di seluruh lokasi sampling di sungai Cikaniki Pongkor. Sebaran fraksi pasir, lumpur dan liat disetiap lokasi sampling dapat dilihat pada Gambar 3. 


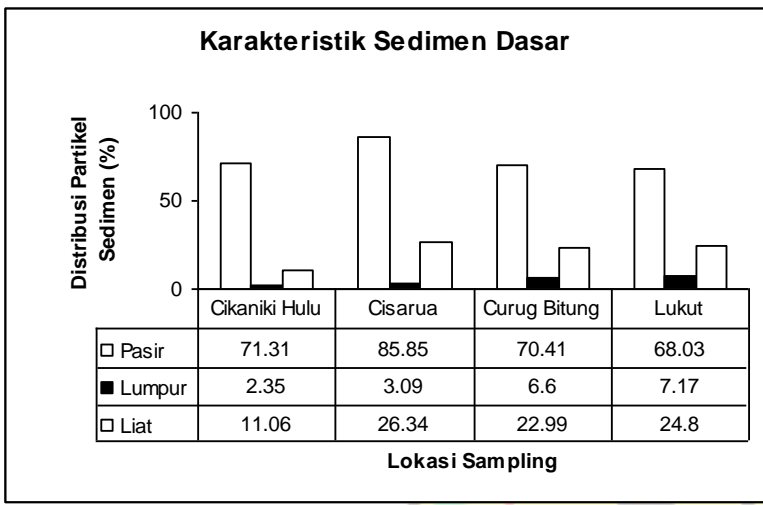

Gambar 3. Hasil Pengukuran Karakteristik Sedimen Dasar

Jenis Substrat di perairan sangat penting diketahui karena sifat logam berat yang memilki kecenderungan untuk terikat pada fraksi sedimen yang halus dan merupakan faktor pembatas bagi penyebaran organisme di dasar perairan tersebut (Wang, et. Al, 2003). Jenis Substrat ini erat kaitannya dengan kandungan oksigen dan ketersediaan nutrient dalam sedimen. Pada Jenis substrat berpasir, kandungan oksigen relatif lebih besar dibandingkan dengan substrat yang halus, karena pada substrat berpasir terdapat pori udara yang memungkinkan terjadinya pencampuran yang lebih intensif dengan air diatasnya. Arus yang kuat tidak hanya menghanyutkan partikel sedimen yang berukuran kecil saja, tetapi juga menghanyutkan nutrien. Sebaliknya pada substrat yang halus, oksigen tidak begitu banyak, tetapi biasanya nutrien tersedia cukup besar, sehingga jenis substrat ini yang disukai oleh makroinvetebrata di dasar perairan. Hal ini juga merupakan masalah apabila terjadi kontaminasi yang besar dari logam berat yang memiliki berat jenis yang lebih besra dari air cenderung mengendap ke substrat sedimen yang halus (McDowell dan O'Connor, 1977 dalam Harymurthy, 2001).

Pada penelitian ini terdapat kecenderungan pengikatan logam berat merkuri yang lebih tinggi pada fraksi sedimen yang halus daripada fraksi sedimen yang kasar, hal ini dapat kita amati pada gambar 4 dan 5 .

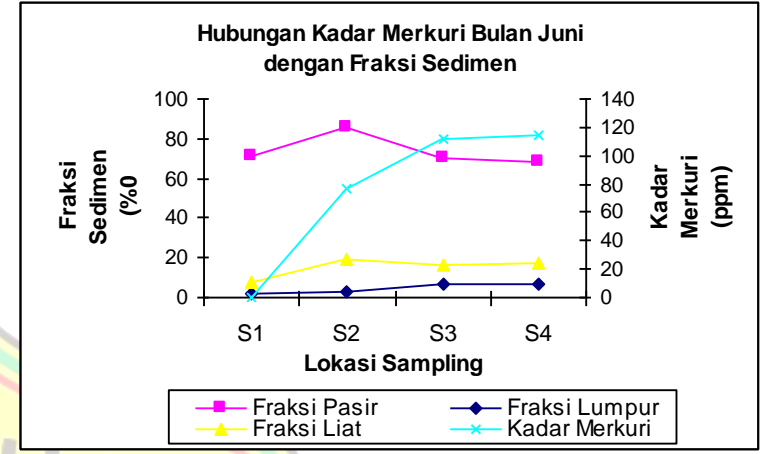

Gambar 4. Grafik Hubungan Kadar Merkuri Bulan Juni dengan Fraksi Sedimen

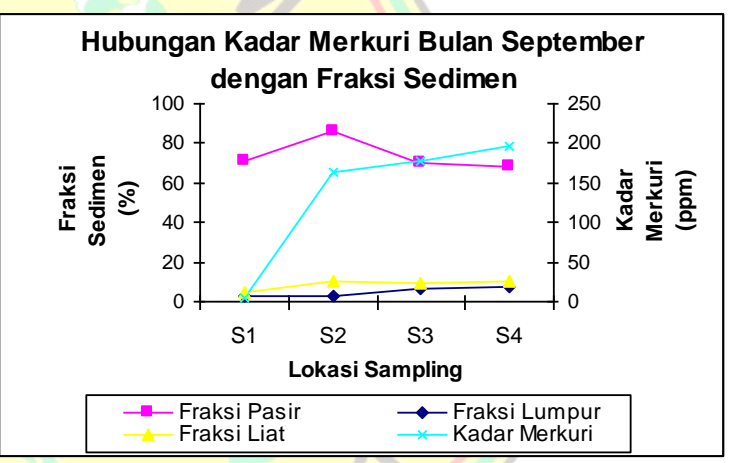

Gambar 4. Grafik Hubungan Kadar Merkuri Bulan Juni dengan Fraksi Sedimen

Berdasarkan gambar 4 dan 5 dapat diamati pada bulan Juni dan September, lokasi sampling S4 (Lukut) memiliki kandungan fraksi sedimen halus (lumpur) tertinggi yang diikuti oleh kadar merkuri yang lebih tinggi dari lokasi sampling yang lain, begitu juga sebaliknya untuk lokasi sampling S2 (Cisarua) yang memiliki kandungan fraksi sedimen kasar (pasir) tertinggi kandungan logam merkurinya lebih kecil dibandingkan lokasi sampling lain.

Pada penelitian ini, hubungan peningkatan kadar merkuri dalam sedimen dengan karakteristik fraksi penyusun sedimen ditentukan dengan analisis korelasi yang dapat diamati dengan nilai koefesien korelasi (r) antara variabel yang diukur (Tabel 1). Koefesien korelasi adalah pengukuran statistik kovarian atau asosiasi antara dua variable. Besarnya koefesien korelasi berkisar antara +1 s/d -1 . Koefesien korelasi 
menunjukkan (strength) hubungan linier dan arah hubungan dua variable acak. Jika Koefesien korelasi positif, maka kedua variable mempunyai hubungan searah. Artinya jika nilai variabel $\mathrm{X}$ tinggi maka nilai variabel $\mathrm{Y}$ akan tinggi pula. Sebaliknya jika korelasi negatif maka kedua variable mempunyai hubungan yang terbalik. Artinya jika nilai variabelX tinggi, maka nilai variabel Y akan menjadi rendah (dan sebaliknya). Nilai koefesien korelasi dihitung dengan rumus sebagai berikut (Sudjana, M.A., 1992):

$$
r=\frac{n \Sigma X i Y-\left(\sum X i\right)\left(\sum Y i\right)}{\sqrt{\left\{n \Sigma X i 2-\left(\sum X i\right) 2\right\}\left\{n \Sigma Y i 2-\left(\sum Y i\right) 2\right\}}}
$$

Tabel 1. Nilai Koefesien Korelasi antara Kadar Merkuri dengan Karakteristik Fraksi

\section{Sedimen (Fraksi Pasir, Lumpur dan Liat)}

\begin{tabular}{|l|c|c|}
\hline \multirow{2}{*}{ Jenis Analisis Korelasi } & \multicolumn{2}{|c|}{ Koefesien Korelasi (r) } \\
\cline { 2 - 3 } & $\begin{array}{c}\text { Bulan } \\
\text { Juni }\end{array}$ & $\begin{array}{c}\text { Bulan } \\
\text { September }\end{array}$ \\
\hline 1. Fraksi Pasir dan Kadar & -0.239 & -0.045 \\
Merkuri & 0.860 & 0.766 \\
2. Fraksi Lumpur dan & 0.785 & 0.850 \\
Kadar Merkuri & & \\
3. 3. Fraksi Liat dan & & \\
Kadar Merkuri & & \\
\hline
\end{tabular}

\section{KESIMPULAN}

Penelitian hubungan karakteristik sedimen dasar terhadap kandungan merkuri akibat pertambangan emas tanpa ijin (peti) pongkor kab. Bogor dapat disimpulkan bahwa bahwa kandungan merkuri telah melewati baku mutu nasional dan internasional, kadar merkuri dalam air sungai bulan juni ttd - 0,046 ppm ; bulan september 0,002 - 0,265 ppm dan sedimen bulan juni $<0.0002-114,713$; bulan september 4,39 $196 \mathrm{ppm}$.

Karakteristik sedimen dasar sungai Cikaniki rata-rata keempat lokasi sampling adalah fraksi pasir $73,9 \%$; lumpur $4,8 \%$; liat $21,3 \%$.

Analisis korelasi menunjukkan adanya hubungan yang positif yang sangat erat antara fraksi halus (lumpur dan fraksi liat) sedimen dengan kadar merkuri dengan nilai koefesien korelasi (r) bulan Juni dan September berkisar antara $0.766-0.860$, sebaliknya korelasi yang negatif antara fraksi kasar (pasir) sedimen dan kadar merkuri dengan nilai koefesien korelasi (r) bulan Juni dan Spetember berkisar antara -0.239 -0.045 .

\section{DAFTAR PUSTAKA}

Chapman, P.M., Wang, F., Janssen, C., Persoone, G., and Allen, H.E., 1998. Ecotoxicology of Metal in Aquatic Sediment; Binding and Release,bioavailability,Risk Assesment and Remediation. Can. Fish Aquat. Sci.J.55:2221-22243

Connell, W.D. dan J.G. Miller, 1995. Kimia dan Ekotoksikologi Pencemaran, UI Press, Jakarta

Halimah, S., 2002. Pengkajian Pencemaran Merkuri da Dampak Akumulasinya Akibat Kegiatan Penambangan Emas. Laporan Penelitian Asdep Urusan Sarana Bapedal Kementrian Lingkungan Hidup. Jakarta

Harymurthy, S., 2001. Tipologi Komunitas Makrozoobentos sebagai Bioindikator Pencemaran Perairan di Muara Sungai Donan Cilacap, Jawa Tengah, Skripsi, Fakultas Perikanan. IPB

Palar, H., 2004. Pencemaran dan Toksikologi Logam Berat. Cetakan 2. Penerbit PT. Rieneka Cipta. jakarta

Sudjana, M.A., 1992. Metode Statistika. Edisi ke 5. Penerbit Tarsito. Bandung

Wang, S.X., Znang, S.Z. dan Shan, X.Q., 2003. Fractionation of heavy metal in different particle size sediments and its relationship with heavy metal pollution. Environ. Toxicol, J. 71:873-880 